\title{
E-COMMERCE NATIONAL MARKET - STUDY FROM THE PERSPECTIVE OF MANIFESTED DEMAND
}

\author{
Laura Cătălina Țimiraş \\ "Vasile Alecsandri” University of Bacau \\ timiras.laura@ub.ro
}

\begin{abstract}
E-commerce market in Romania recorded the lowest level of development compared to other EU countries, in terms of the intensity of online purchase habit of the population of Romania. Thus, in 2014, only $16.7 \%$ of those who used the computer in the range of 16-74 years and $10 \%$ of the total population of the same age had made online purchases, compared with $63.3 \%$ and $50 \%$ respectively - the same indicators at EU level. Still, in Romania there was a rapid increase in the share of those who make online purchases, so in 8 years (2007-2014) this indicator increased by 3 times. Regarding the categories of the population by various characteristics, greater orientation towards online purchases is recorded among individuals with high formal education, youth (under 35), with above-average incomes. In terms of product categories purchased online, the most favorite categories are: clothes, sports goods. This analysis is based mostly on official statistics provided by Eurostat.
\end{abstract}

\section{Keywords}

e-commerce market; turnover from e-commerce; orders over internet; structure of demand on internet

\section{JEL Classification}

M31

E-commerce market in Romania has been in recent years in a continue development. According to data from EMOTA - European Multi-channel and Online Trade Association (data resulting from research conducted by eNet Internet Research and Consulting), turnover in 2012 from e-commerce in Romania was 647 million euros. Compared to 2006, turnover growth of e-commerce was more than 8 times, the level estimated for 2016 amounting to over 1.1 billion Euro.

Viewed from the degree of manifestation of the demand, e-commerce market in Romania has registered a dynamic that far exceeded the EU average. However, the degree of "penetration" of this form of commerce is still at a level that places our country in last place among the EU countries. In fact, in Romania we can see both a reduced access of the population to technology (it is the EU country that recorded after Bulgaria, the lowest share of those who used the computer in 2014) and a low manifestation of this buying habit of those who use the computer (it recorded the lowest percentage of those who made online purchases in all those who use the computer at EU level in 2014), according to data from Eurostat.

\section{Orientation of population towards online purchases at national level during 2007 - 2014}

In Romania, in $2014,10 \%$ of the population of $16-74$ years made online shopping in the last 12 months of the reporting period. In the period 2007 - 2014 this indicator has registered a spectacular increase (more than 3 times). Relating to the EU average, we 
find that in Romania the share of people who made online purchases in the total population of 16-74 years is still far from that average, but, however, is growing over time, because of the strong growth recorded nationally compared to lower dynamics at UE level (in the European Union, the analyzed indicator increased by $67 \%$ in the reference period). Thus, if in 2007 the share of population in our country who made online purchases in the total population of 16 - 74 years made up $10 \%$ compared to the EU average (90\% below average), in 2014 it represented $20 \%$ of EU average (80\%) below average. (Figure 1)
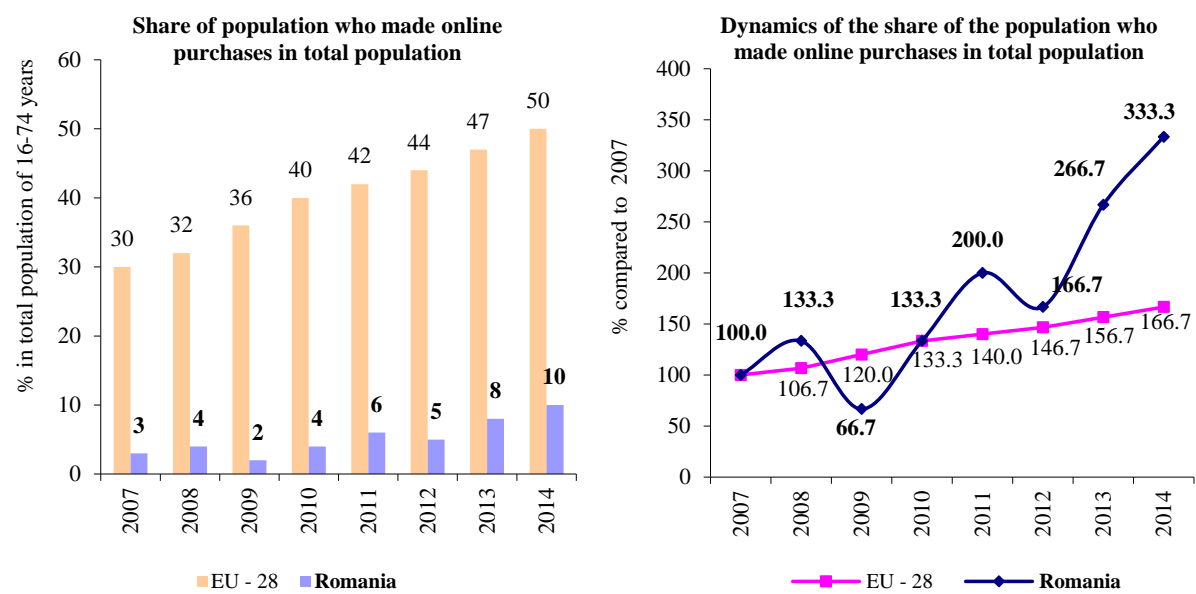

Figure 1 Evolution of the share of people who made online purchases in the total population of 16-74 years in Romania and European Union

Source: own processing from Eurostat data

Note: are considered people who have used computer / made online purchases for private use in the last 12 months of the reporting period. The data refer to the population of 16-74 years

\section{The usage of computer in Romania between 2007 and 2014}

Making purchases online is largely influenced by people's access to technology, Romania being from this point of view far from the EU average. Thus, in 2014, 60\% of the population of 16-74 years used the computer, compared to $79 \%$ EU average. In time, the mentioned indicator followed an upward trend, exceeding the EU average (in the 2007-2014 period the proportion of people who used the computer in total population of $16-74$ years increased by $57.9 \%$ nationally and $21.5 \%$ at EU level). (Figure 2)

The link between the use of computer and orientation of the population towards online purchases in Romania between 2007 and 2014

In fact, between the development of the two national indicators presented above there is a strong and significant correlation, increased access to technology or computer using generating an increase in orientation of Romanian population towards online purchases; on average, in the 8 years analyzed, for each 100 new users of computer there are 29 new online buyers (Figure 3 and Table 1) 

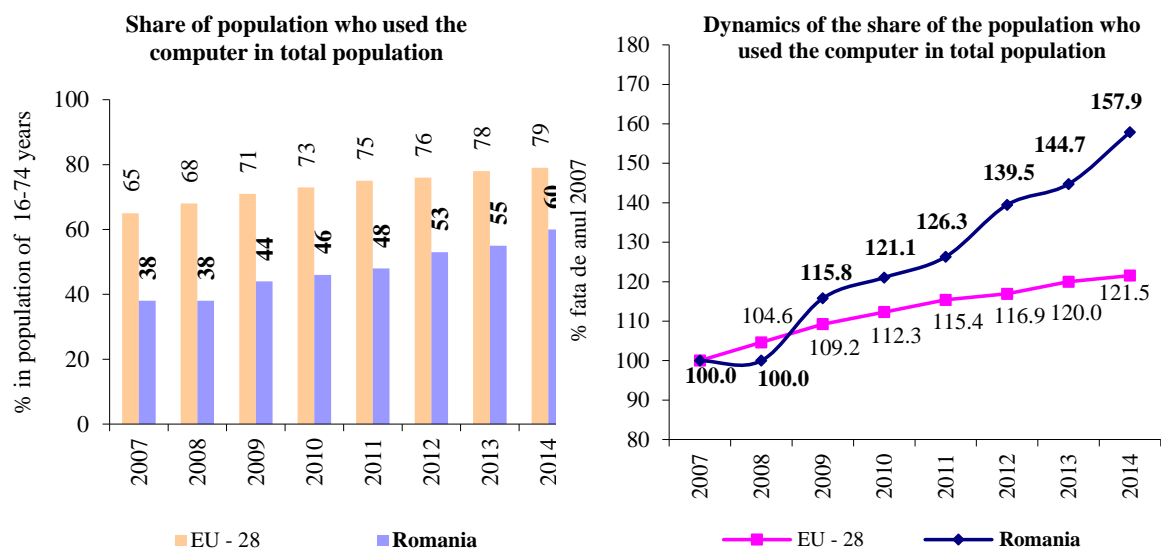

Figure 2 The dynamics of the share of population who used the computer in total population of 16-74 years in Romania and the European Union

Source: own processing from Eurostat data

Note: are considered people who have used computer / made online purchases for private use in the last 12 months of the reporting period. The data refer to the population of $16-74$ years

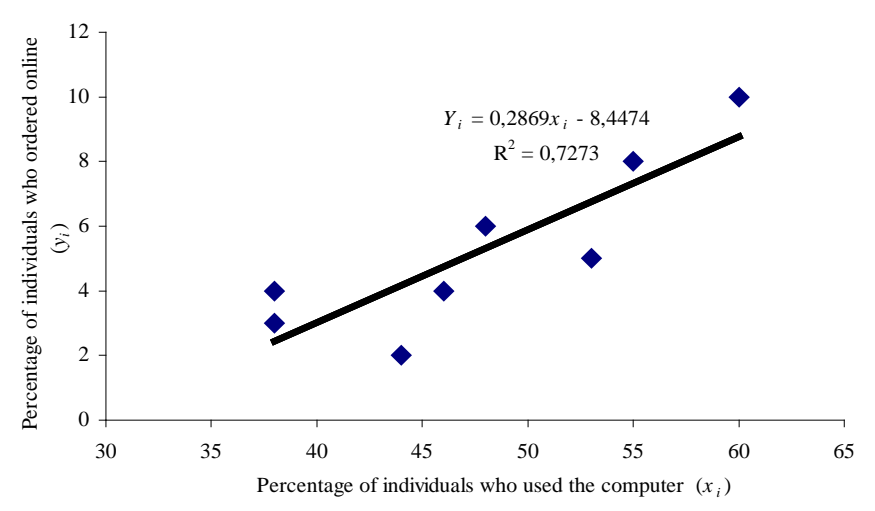

Figure 3 The link between the share of those who used the computer and the share of those who bought online in Romania during 2007-2014

Source: own processing from 2015 Eurostat data

Note: are considered people who have used computer / made online purchases for private use in the last 12 months of the reporting period. The data refer to the population of 16-74 years

Table 1 The relationship between the percentage of those who used the computer $\left(x_{i}\right)$ and the percentage of those who shop online $\left(y_{i}\right)$ in Romania during 2007-

2014

\begin{tabular}{|c|c|c|c|c|c|c|c|}
\hline $\begin{array}{l}\text { Regression } \\
\text { equation }\end{array}$ & \multicolumn{2}{|c|}{$\begin{array}{l}\text { Variation (sum of } \\
\text { the squares) }\end{array}$} & $\begin{array}{l}\text { Coefficient of } \\
\text { determination }\end{array}$ & $\begin{array}{l}\text { Correlation } \\
\text { coefficient }\end{array}$ & $\begin{array}{l}\text { Calculated } \\
\text { F-Value }\end{array}$ & $\begin{array}{l}\text { Significan } \\
\text { ce level }\end{array}$ & $\begin{array}{l}\text { Theoreti } \\
\text { cal F- } \\
\text { Value }\end{array}$ \\
\hline \multirow{3}{*}{$\begin{array}{l}Y_{i}=0,2869 \\
x_{i}=8,4474\end{array}$} & Total & 49,5 & \multirow{3}{*}{$72,73 \%$} & \multirow{3}{*}{0,85} & \multirow{3}{*}{16,0} & \multirow{3}{*}{0,05} & \multirow{3}{*}{5,99} \\
\hline & Factorial & 36,0 & & & & & \\
\hline & Residual & 13,5 & & & & & \\
\hline
\end{tabular}

Source: own processing from 2015 Eurostat data

Note: are considered people who have used computer / made online purchases for private use in the last 12 months of the reporting period. The data refer to the population of 16-74 years 
Increasing the share of those who made online purchases in Romania's total population of 16-74 years was not only on account of the increasing of the number of computer users, but also as a result of the habit of buying goods on the Internet of the computer users (Figure 4). Thus, the increase in the period 2007 - 2014 of 3.33 times of the share of those who made online purchases was generated by the increase of $58 \%$ of the share of users of computers, and by the 2.1 times increase in the share of those who did online purchases in total computer users. On yearly average, the increasing by $18.8 \%$ in the share of those who bought from the Internet in the total population of 16-74 years in Romania was generated by a $6.7 \%$ increase in the proportion of computer users and by $11.3 \%$ increase of the share of users who purchased online. (Table 2)

Table 2 Decomposition by the factors which influenced the dynamics of the share of those who made online purchases

\begin{tabular}{|l|c|c|}
\hline \multicolumn{1}{|c|}{ Indicator } & $\begin{array}{c}\text { Dynamics in 2014 } \\
\text { compared to 2007 (\%) }\end{array}$ & $\begin{array}{c}\text { The average annual relative change } \\
\text { in the period 2007 - 2014 (+/- \%) }\end{array}$ \\
\hline Percentage of Individuals who purchased online & 333.3 & 18.8 \\
\hline Percentage of individuals who used your computer & 157.9 & 6.7 \\
\hline $\begin{array}{l}\text { The share of those who made online purchases in all } \\
\text { those who used the computer }\end{array}$ & 211.1 & 11.3 \\
\hline
\end{tabular}

Source: own processing from 2015 Eurostat data

Note: are considered people who have used computer / made online purchases for private use in the last 12 months of the reporting period. The data refer to the population of 16-74 years

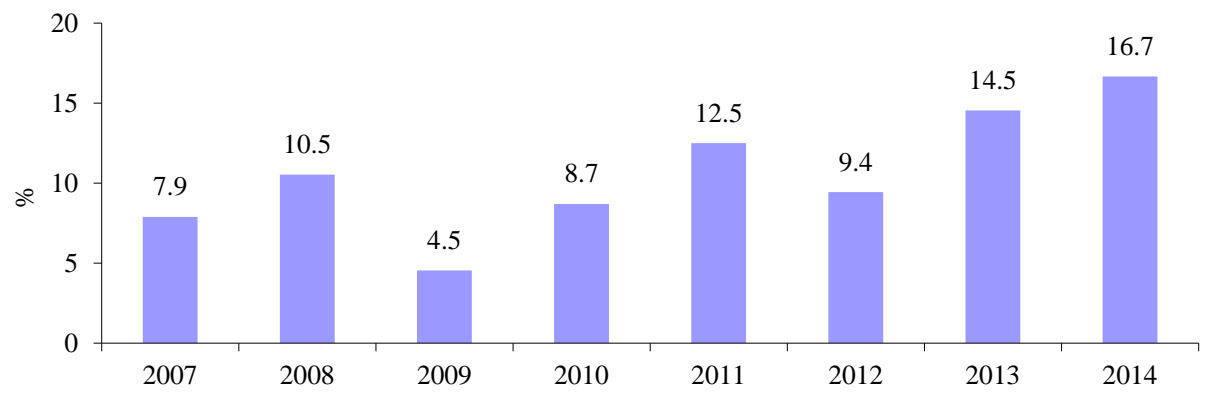

Figure 4 Evolution of the share of people who made online purchases in total computer users of 16-74 years in Romania during 2007-2014

Source: own processing from 2015 Eurostat data

Note: are considered people who have used computer / made online purchases for private use in the last 12 months of the reporting period. The data refer to the population of 16-74 years

\section{Economic and demographic characteristics of online consumers}

On economic and demographic groups in the population there are significant differences in terms of online shopping habit (Table 3).

Thus, considering the age, a much higher percentage of those who buy online are recorded in age groups under 45 years compared to those over 45 . The accelerated dynamics of this indicator was recorded in the age groups of 35-44, 25-34 respectively. In the categories of population by sex there is not a substantial differences in terms of online shopping habit.

Considering the education, the largest share of those who make purchases online are individuals with high formal education, followed by individuals with medium formal education. In fact, according to this criterion there are found the greatest differences in population groups. 
Also, a higher percentage of those who buy online are found among people with higher incomes, increased purchasing power being accompanied by greater orientation towards this form of distribution.

Table 3 Evolution of the share of people who made online purchases in the total population into categories by different economic and demographic criteria in the period 2007-2014 (\%)

\begin{tabular}{|c|c|c|c|c|c|c|c|c|}
\hline Year & 2007 & 2008 & 2009 & 2010 & 2011 & 2012 & 2013 & 2014 \\
\hline \multicolumn{9}{|c|}{ Categories of population by age } \\
\hline 16 to 24 years old & 5 & 7 & 4 & 6 & 9 & 9 & 12 & 17 \\
\hline 25 to 34 years old & 4 & 7 & 3 & 7 & 11 & 9 & 15 & 18 \\
\hline 35 to 44 years old & 2 & 3 & 3 & 3 & 5 & 5 & 9 & 12 \\
\hline 45 to 54 years old & 2 & 2 & 1 & 2 & 3 & 4 & 6 & 7 \\
\hline 55 to 64 years old & 1 & 1 & 0 & 1 & 1 & 2 & 3 & 3 \\
\hline 65 to 74 years old & n.d. & n.d. & 0 & n.d. & 0 & 0 & 1 & 1 \\
\hline \multicolumn{9}{|c|}{ Categories population by gender } \\
\hline Males & 3 & 4 & 2 & 4 & 6 & 6 & 9 & 11 \\
\hline Females & 2 & 3 & 2 & 3 & 5 & 5 & 8 & 10 \\
\hline \multicolumn{9}{|c|}{ Categories of population by level of education * } \\
\hline $\begin{array}{l}\text { Individuals with no or low formal } \\
\text { education }\end{array}$ & 1 & 1 & 0 & 1 & 1 & 2 & 2 & 3 \\
\hline $\begin{array}{l}\text { Individuals with medium formal } \\
\text { education }\end{array}$ & 2 & 3 & 2 & 3 & 5 & 4 & 7 & 9 \\
\hline $\begin{array}{c}\text { Individuals with high formal } \\
\text { education }\end{array}$ & 12 & 17 & 10 & 15 & 22 & 18 & 28 & 31 \\
\hline \multicolumn{9}{|c|}{ Categories of population by income levels } \\
\hline $\begin{array}{l}\text { Individual living in a household } \\
\text { with income in first quartile }\end{array}$ & n.d. & 1 & 0 & 0 & 1 & 1 & 2 & 3 \\
\hline $\begin{array}{l}\text { Individual living in a household } \\
\text { with income in second quartile }\end{array}$ & n.d. & 1 & 0 & 1 & 2 & 3 & 4 & 6 \\
\hline $\begin{array}{l}\text { Individual living in a household } \\
\text { with income in third quartile }\end{array}$ & n.d. & 2 & 1 & 3 & 4 & 5 & 9 & 9 \\
\hline $\begin{array}{l}\text { Individual living in a household } \\
\text { with income in fourth quartile }\end{array}$ & n.d. & 7 & 4 & 7 & 11 & 9 & 13 & 16 \\
\hline
\end{tabular}

Source: own processing from 2015 Eurostat data

*according to ISCED 2011

Note: are considered people who made online purchases for private use in the last 12 months of the reporting period. The data refer to the population of $16-74$ years

n.d. - no data

\section{Categories of goods or services ordered over the Internet}

Regarding the categories of goods purchased online, clothes, sports goods are most preferred, in 2014, 58\% of 16-74 years making Internet purchases of such goods. Other categories of goods purchased in Internet (but the percentage of those who made such purchases in the total population is well below the level of category of clothes and sports goods) are: books / magazines / e-learning and electronic equipment.

Over time, in the period 2007-2014, we can see an increase in e-commerce for clothes, sports goods, food / groceries, tickets for events (the share of those who bought such goods on the Internet increasing by 3 times) and a diminished orientation of consumers for categories: computer software, films / music, books / magazines / e-learning, shares / financial services / insurance and computer hardware. (Table 4) 
Table 4 Evolution of the percentage of individuals who ordered goods or services, over the Internet, for private use in 2007-2014 period

\begin{tabular}{|c|c|c|c|c|c|c|c|c|}
\hline Categories of goods or services & 2007 & 2008 & 2009 & 2010 & 2011 & 2012 & 2013 & 2014 \\
\hline \multicolumn{9}{|c|}{ Percentage of individuals who ordered goods or services, over the Internet, for private use (\%) } \\
\hline Food/ groceries & 2 & 4 & 5 & 5 & 7 & 11 & 8 & 6 \\
\hline Clothes, sports goods & 19 & 21 & 38 & 36 & 53 & 53 & 54 & 58 \\
\hline Electronic equipment & 14 & 12 & 20 & 17 & 22 & 19 & 16 & 21 \\
\hline Computer software & 32 & 28 & 29 & 32 & 31 & 12 & 15 & 9 \\
\hline Computer hardware & 14 & 11 & 18 & 15 & 17 & 8 & 7 & 11 \\
\hline $\begin{array}{l}\text { Shares/ financial services/ } \\
\text { insurance }\end{array}$ & 4 & 2 & 2 & 6 & 4 & 6 & 3 & 3 \\
\hline Films/ music & 46 & 44 & 31 & 35 & 32 & 22 & 20 & 15 \\
\hline Household goods & 13 & 9 & 9 & 12 & 13 & 12 & 19 & 16 \\
\hline Tickets for events & 6 & 12 & 19 & 24 & 27 & 18 & 19 & 18 \\
\hline $\begin{array}{l}\text { Books/ magazines /e-learning } \\
\text { material }\end{array}$ & 47 & 58 & 47 & 56 & 50 & 40 & 41 & 29 \\
\hline \multicolumn{9}{|c|}{ Dinamics of percentage of individuals who ordered goods or services, over the Internet, for private use (2007=100\%) } \\
\hline Food/groceries & 100 & 200 & 250 & 250 & 350 & 550 & 400 & 300 \\
\hline Clothes, sports goods & 100 & 111 & 200 & 189 & 279 & 279 & 284 & 305 \\
\hline Electronic equipment & 100 & 86 & 143 & 121 & 157 & 136 & 114 & 150 \\
\hline Computer software & 100 & 88 & 91 & 100 & 97 & 38 & 47 & 28 \\
\hline Computer hardware & 100 & 79 & 129 & 107 & 121 & 57 & 50 & 79 \\
\hline $\begin{array}{l}\text { Shares/ financial services/ } \\
\text { insurance }\end{array}$ & 100 & 50 & 50 & 150 & 100 & 150 & 75 & 75 \\
\hline Films/music & 100 & 96 & 67 & 76 & 70 & 48 & 43 & 33 \\
\hline Household goods & 100 & 69 & 69 & 92 & 100 & 92 & 146 & 123 \\
\hline Tickets for events & 100 & 200 & 317 & 400 & 450 & 300 & 317 & 300 \\
\hline $\begin{array}{l}\text { Books/ magazines /e-learning } \\
\text { material }\end{array}$ & 100 & 123 & 100 & 119 & 106 & 85 & 87 & 62 \\
\hline
\end{tabular}

Source: own processing from 2015 Eurostat data

Note: are considered people who made online purchases for private use in the last 12 months of the reporting period. The data refer to the population of $16-74$ years

\section{Conclusions}

The national market for e-commerce, although well below the EU average, has shown a strong dynamics, as reflected in rising share of the population who make purchases online. This increase was driven by increasing people's access to technology and as a result of the habit of online buying of an increasing number of EU consumers. Thus, in 2014, $10 \%$ of the population of 16-74 years have made in the last 12 months of the reporting period online shopping, indicator which in the period 2007-2014 grew by 3.3 times. This growth was driven by the increase with $58 \%$ of the share of computers users, but also by the 2.1 times increase in the share of those who made online purchases in total computer users. The categories of the population who registered the largest online purchases orientation are: individuals with high formal education, young people under 35 and those with above-average incomes. The main product categories purchased in the online environment are: clothes and sports goods, and to a lesser extent: books / magazines / e-learning and electronic equipment.

\section{References}

Kumar, V., Aaker, D.A., Day G.S. (1999), Essentials of Marketing research, John Wiley \& Sons, Inc., New York Chichester Weinheim Brisbane Singapore Toronto 
Zait, L. (2009), Les courtiers en information - une nouvelle tendance dans la restructuration des chaines de distribution, The Annals of University of Oradea. Economic Sciences, TOM XVIII, vol. 4, pp. 877 - 881

EMOTA (European Multi-channel and Online Trade Association), available at http://www.emota.eu/

Eurostat, available at http://ec.europa.eu/eurostat/data/database 